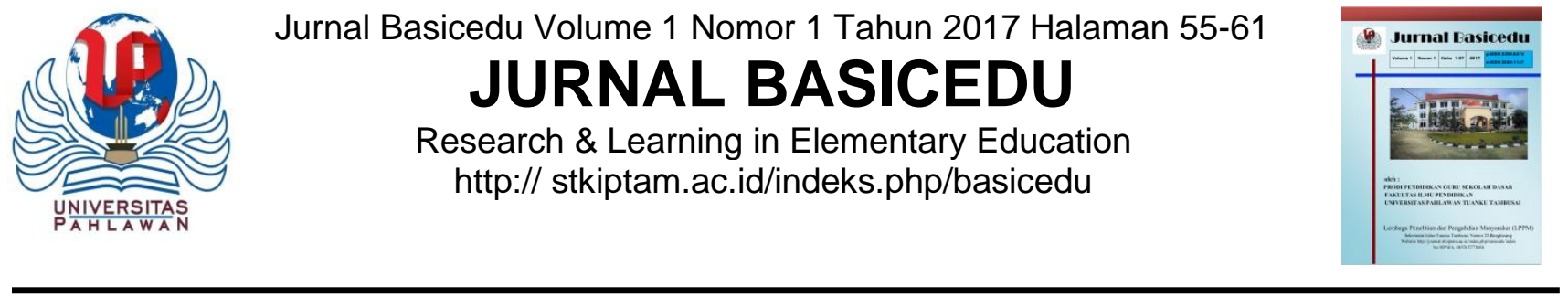

\title{
PENINGKATAN PROSES PEMBELAJARAN TEMATIK DENGAN MODEL KOOPERATIF TIPE TGT DI KELAS III SD NEGERI 18 LANGGINI BANGKINANG
}

\author{
Putri Hana Pebriana ${ }^{1}$ \\ ${ }^{1}$ Dosen Prodi PGSD Universitas Pahlawan Tuanku Tambusai \\ e-mail : putripebriana99@gmail.com
}

\begin{abstract}
This research was conducted as the thematic learning process in class III of SD Negeri 18 Langgini Bangkinang was not run as it was expected. This made the students' social skill was not developedmaximally. Therefore, this research sought to improve the thematic learning processby using TGT cooperative learning model.This was a Classroom Action Research which was conducted in two cycles inwhich each cycle consisted of four phases covering planning, acting, observing andreflecting. The subject of the research was the teacher and 33 students; 17 malestudents and 16 female students. The data was collected through observation.The results of the research disclosed that the use of TGT cooperative learning modelcould improve the thqatic learning process in class III of SD Negeri 18 Langgini Bangkinang. In the first cycle, ingroup works, the students' score in tolerance attitude was 52,98, their activeness towork in group was 59,33, their ability to present their work was 56,07, and theircourage to express ideas was 57,08. Meanwhile their average score in Indonesian was5,29, in Social Science was 7,53, in Natural Science was 6,21 and in Mathematicswas 7,19, or in general their average score was less than adequate.In the second cycle, their score in tolerance attitude was 85,59, theiractiveness to work in group was 85,95; their ability to present their work was 87,41, and their courage to express ideps was 86,64. Meanwhile their average score inlndonesian was 8,01, in Social Science was 8,02, in Nafural Science was 8,79 and inMathematics was 9,07, or in general their average score was good.Hence, the thematiq leaming could be improved by using TGT cooperativelearning model. This could be seen from the significant improvement of the thematiclearning process from the first cycle to the second one either in pre-teaching, whilstteachingor post-teaching..
\end{abstract}

Kata Kunci : Team Games Tournament,Thematic Learning 


\section{PENDAHULUAN}

Pembelajaran merupakan suatu proses interaksi belajar dan mengajar antara guru dan peserta didik yang bertujuan agar peserta didik memiliki kemampuan dan kepribadian sesuai dengan kehidupan dan budaya masyarakat. Menurut Hamalik (2012:63) pembelajaran adalah suatu upaya untuk mempersiapkan peserta didik untuk menjadi warga masyarakat yang baik, karena dengan pembelajaran yang efektif akan meningkatkan rasa percaya diri dan sikap positif peserta didik, yang merupakan bekal dalam hidup bermasyarakat.

Sesuai karakteristik belajar anak usia $\mathrm{SD}$, maka pendekatan yang tepat digunakan adalah pendekatan tematik, karena dengan pendekatan tematik peserta didik dapat memperoleh pengalaman langsung dan terlatih untuk dapat menemukan sendiri berbagai pengetahuan yang yang dipelajari secara holistik dan bermakna. Permendiknas No.22 tahun 2006 (2006:7) tentang Standar Isi, menyatakan bahwa pembelajaran pada kelas I sampai dengan kelas III SD dilaksanakan melalui pendekatan tematik.

Berdasarkan hasil observasi di kelas III di Sekolah Dasar SD Negeri 18 Langgini Bangkinang pada tanggal 17 Desember 2015, proses pembelajaran tematik yang dilakukan guru belum efektif, walaupun guru merasa sudah melakukan pembelajaran tematik, hal ini dapat dilihat yaitu proses pembelajaran masih terpisah-pisah dalam mata pelajaran, pembelajaran masih didominasi oleh guru, hal ini dapat dilihat guru selalu melakukan komunikasi searah pada kegiatan awal pembelajaran. Pada kegiatan inti yang seharusnya melibatkan peserta didik dalam kegiatan kerja kelompok hanya dilakukan dengan metode ceramah, dan pada kegiatan akhir pembelajaran akhir guru tidak mengambil kesimpulan, hal ini dapat dilihat guru langsung penutup pembelajaran dengan pemberikan pekerjaan rumah.

Hasil observasi juga menunjukkan bahwa Peserta didik kurang aktif dalam pembelajaran. Hal ini terlihat dari peserta didik kurang tanggap dengan pertanyaan guru, sehingga sebagian besar tidak dapat menjawab pertanyaan guru. Disaat temannya menjawab peserta didik lain juga kurang menghargai, dengan sikap acuh dan apabila ada kesalahan dalam menjawab pertanyaan mencemoohnya.

Selain itu, guru kurang dapat memotivasi peserta didik, proses pembelajaran membosankan. Hal ini dapat dilihat banyak peserta didk yang gelisah dan beberapa peserta didik sering keluar kelas dengan alasan buang ar kecil. Guru kurang melibatkan peserta didik untuk bisa bekerja sama antar mereka maupun dengan guru. Peserta didik cenderung bekerja sendiri-sendiri, hal ini dapat dilihat hampir tidak pernah di kelas awal terjadi diskusi.

Dari hasil wawancara dengan guru, diperoleh data bahwa guru tidak pernah menerapkan model pembelajaran kooperatif karenaguru menganggap peserta didik kelas awal belum bisa diskusi dengan baik.Guru tidak terbiasa mengambil kesimpulan akhir dari hasil wawancara guru menganggap apabila peserta didik sudah dapat memahami pembelajaran yang dapat dilihat dari hasil tes yang sudah baik, maka tidak perlu lagi mengambil kesimpulan pembelajaran.

Dari berbagai permasalahan di atas peneliti menyimpulkan bahwa pembelajaran tematik yang dilaksanakan di kelas III Negeri 18 belum efektif. Salah satu penyebab dari permasalahan ini adalah guru tidak menggunakan model pembelajaran kooperatif. Untuk mengatasi permasalah pembelajaran tematik tersebut peneliti berkolaborasi dengan guru kelas III SD Negeri 18 dengan menggunakan model kooperatif (Cooperatif Learning), karena pembelajaran kooperatif memberikan kesempatan pada peserta didik untuk berlatih bekerja sama dalam kelompok yang heterogen. Dengan bekerja sama dalam kelompok heterogen, kemampuan peserta didik yang beragam akan saling melengkapi dan saling berbagi, sehingga dapat meningkatkan proses pembelajaran tematik.

Model Pembelajaran yang dipilih dalam penelitian ini adalah Cooperatif Learning tipe Teams-Games-Tournament $(T G T)$. Model pembelajaran ini dipilih karena 
dalam pelaksanaannya terdapat unsur permainan (game) yang merupakan aktifitas yang sangat disukai oleh peserta didik usia kelas awal SD. Sehingga dapat meningkatkan motivasi peserta didik agar aktif dalam melaksanakan proses pembelajaran.

Menurut Slavin (2009:163) model TGT merupakan salah satu bentuk pembelajaran kooperatif dengan menggunakan turnamen akademik, dan menggunakan kuis-kuis serta sistem skor kemajuan individu, dimana peserta didik berlomba sebagai wakil tim mereka dengan anggota lain yang bekerja. Ada lima komponen utama dalam $T G T$, yaitu (1) penyajian kelas, (2) kelompok, (3) pemainan, (4) turnamen, (5) penghargaan kelompok.

Berdasarkan uraian di atas peneliti merumuskan penelitian ini dengan judul "Peningkatan Proses Pembelajaran Tematik dengan Model Kooperatif Tipe TGT Di Kelas III SD Negeri 18 Langgini Bangkinang”.

\section{METODE}

Sesuai dengan masalah dan tujuan penelitian sebagaimana diuraikan pada bab sebelumnya, maka penelitian ini menggunakan rancangan penelitian tindakan kelas. Rancangan penelitian ini dipilih karena memiliki karakteristik yang sesuai dengan tujuan penelitian yaitu untuk meningkatkan pembelajaran tematik di kelas. Pemilihan rancangan penelitian ini sesuai pula dengan hakekat penelitian tindakan yang dikemukakan oleh Kemmis dalam Wiriatmaja (2008:12) bahwa penelitian tindakan adalah sebuah bentuk inkuiri reflektif yang dilakukan secara kemitraan dalam situasi sosial, yaitu situasi pendidikan yang bertujuan untuk meningkatkan proses rasionalitas dan keadilan dari praktek-praktek pendidikan sehari-hari.

Prosedur pelaksanaan penelitian tindakan terdiri atas beberapa tahap. Menurut pendapat Lewin dalam Wiriatmaja (2008:64), siklus aktifitas dasar dalam penelitian tindakan meliputi: identifikasi ide awal, analisis, menemukan masalah umum, perencanaan umum tindakan, mengembangkan langkah tindakan pertama, melaksanakan langkah tindakan pertama, mengevaluasi, merevisi perencanaan umum, berdasarkan siklus dasar ini peneliti kemudian mengulang dan mengembangkannya pada langkah tindakan kedua, mengevaluasi, merevisi rancangan umum, untuk mengembangkan langkah selanjutnya bila diperlukan. Lebih kongkritnya setiap siklus melalui tahap-tahap: merencanakan tindakan, pelaksanaan, observasi, dan refleksi.

Data penelitian ini berupa hasil pengamatan, wawancara, hasil catatan lapangan, dan dokumentasi dari setiap tindakan pembelajaran tematik dengan menggunakan model kooperatif tipe $T G T$ di kelas III SD Negeri 18 Langgini. Data tersebut berkaitan dengan data perencanaan, pelaksanaan, dan hasil pembelajaran tematik sebagai berikut:

Data perencanaan berkaitan dengan penyusunan rancangan pembelajaran yang meliputi cara menentukan bahan pembelajaran dan merumuskan tujuan, mengembangkan dan mengembangkan pengalaman belajar, media, dan sumber belajar, merencanakan prosedur, jenis, dan menyiapkan alat penilaian.

Data tentang pelaksanaan pembelajaran berhubungan dengan interaksi antar peserta didik, interaksi antara guru dan peserta didik, dalam pembelajaran tematik dengan model kooperatif tipe TGT.

Data Hasil Pembelajaran tematik dengan menggunakan model kooperatif tipe $T G T$ di kelas III SD Negeri 18 Langgini. Data tentang hasil pembelajaran tematik sebelum dan sesudah pelaksanaan tindakan pembelajaran tematik dengan model kooperatif tipe $T G T$.

Sumber data penelitian ini diambil dari guru dan peserta didik kelas III SD Negeri 18 Langgini 2015/2016. Sumber data penelitian adalah proses kegiatan pembelajaran tematik pada tahap kegiatan awal, inti, akhir dengan menggunakan kooperatif tipe TGT.

Penelitian ini dilaksanakan di SD Negeri 18 Langgini Bangkinang. Penelitian dilakukan terhadap subjek penelitian yang meliputi guru dan peserta didik kelas III. 
Subjek dalam penelitian ini adalah peserta didik kelas III SD Negeri 18 Langgini yang terdaftar pada semester II tahun ajaran 2015/2016. Berdasarkan data administrasi yang ada di sekolah serta wawancara dengan guru kelas, peserta didik kelas III memiliki latar belakang sebagai berikut: (1) jumlah seluruh peserta didik di kelas tersebut adalah 33 orang yang terdiri dari laki-laki 17 orang dan perempuan 16 orang, (2) usia peserta didik rata-rata 9 tahun, (3) latar belakang pekerjaan orang tua peserta didik pada umumnya adalah pegawai negeri, (3) latar belakang pendidikan orang tua peserta didik sebagaian besar adalah sarjana

Selain peserta didik subjek penelitian adalah guru kelas III SD Negeri 18 Langgini wanita berijazah $\mathrm{S} 1$ dengan masa kerja lima tahun. Data penelitian ini akan dikumpulkan dengan menggunakan teknik observasi,wawancara, catatanlapangan, dan teknik tes. Instrumen penelitian yang akan digunakan adalah berupa lembaran observasi dan tes hasil belajar.

Data yang diperoleh dalam penelitian dianalisis dengan menggunakan data kualitatif sebagaimana Goetz dan Le Compte dalam wiriatmaja (2008: 137) yaitu analisis data dimulai dengan menelaah sejak pengumpulan data sampai seluruh data terkumpul. Data tersebut direduksi berdasarkan masalah yang diteliti, diikuti penyajian data dan terakhir penyimpulan.

$\begin{array}{lll} & \text { Analisis data dilakukan terhadap data } \\ \text { yang telah direduksi, baik data } & \\ \text { perencanaan,pelaksanaan maupun data }\end{array}$
evaluasi. Analisis data dilakukan dengancara terpisah-pisah. Hal ini dimaksud agar dapat ditemukanberbagai informasi yang spesifik dan terfokus pada berbagai informasi yang mendukung pembelajaran dan yang menghambat pembelajaran. Dengan demikian pengembangan dan perbaikan atas berbagai kekurangan dapat dilakukan tepat pada aspek yang bersangkutan.

\section{Pembahasan Siklus I}

Pelaksanaan pembelajaran pada tahap kegiatan inti dimulai guru dengan presentasi kelas yaitu fase 1 model kooperatif tipe TGT. Guru menayangkan gambar lewat infokus yang berkenaan dengan topik pembelajaran. Siklus 1 dengan tema pekerjaan yang menghasilkan barang dan jasa, gambar diamati oleh peserta didik dengan teliti, kemudian guru membacakan cerita dan menanyakan tentang peristiwa yang terjadi dalam cerita. Peserta didik juga menceritakan kembali cerita yang telah didengar dari guru. serta memberikan pertanyaan tentang cara menghargai berbagai pekerjaan.

Sebagaimana pendapat Slavin (2008:170) aktifitas TGT terdiri dari lima komponen yaitu penyajian kelas (teach). Yaitu dilakukan dengan pengajaran langsung atau ceramah, diskusi yang dipimpin guru, demonstrasi atau eksperimen tergantung pada karakteristik materi yang sedang disampaikan dan ketersediaan media di sekolah yang bersangkutan. Pada kesempatan ini guru harus memberitahu peserta didik agar cermat mengikuti proses pembelajaran, karena informasi yang diterima pada fase ini sangat untuk bisa menjawab kuis pada fase berikutnya dan skor kuis yang akan diperoleh sangat menentukan skor tim mereka.

Kegiatanberikutnya membentuk kelompok secara heterogen (fase 2) Peserta didik membentuk kelompok heterogen dengan arahan dari guru, kemudian peserta didik diskusi kelompok dengan berdasarkan LKP yang dibagikan guru yang berkaitan dengan tujuan pembelajaran.

Sebagaimana pendapat Slavin (2008:170) aktifitas TGT terdiri dari lima komponen, yaitu pada fase 2 (belajar kelompok). Pada fase ini guru membentuk kelompok-kelompok kecil heterogen beranggotakan 3-4 orang peserta didik, terdiri dari peserta didik berkemampuan tinggi, sedang dan kurang. Fungsi kelompok disini adalah untuk mengarahkan semua anggota untuk belajar mengkaji materi yang disampaikan oleh guru, berdiskusi, membantu 
anggota yang kemampuan akademiknya kurang sehingga mereka secara tim nantinya siap untuk mengikuti kuis. Kekompakan kerja sama tim akan mampu meningkatkan hubungan antar sesama anggota tim, rasa percaya diri, dan keakraban antar peserta didik. Sebagaimana menurut Raharjo dan Daryanto (2012:242) bahwa tujuan dari pembelajaran kooperatif adalah meningkatkan hasil belajar peserta didik dan penerimaan berbagai keragaman dari temannya, serta mengembangkan ketrampilan sosialnya.

Berdasarkan

pengamatan

peneliti,peserta didik belum terbiasa melakukan diskusi kelompok. Hal ini dapat dilihat dari hasil observasi penilaian selama peserta didik melakukan diskusi kelompok yang masih rendah. Aspek yang diamati saat diskusi kelompok adalah sikap toleransi peserta didik dalam diskusi kelompok, keaktifan peserta didik, kemampuan dalam mempresentasikan hasil kerja kelompok, dan keberanian peserta didik dalam mengungkapkan pendapat.

Kegiatan pembelajaran selajutnya dilakukan oleh peserta didik adalah fase III dan fase IV, yaitu melakukan games turnamen, dengan posisi peserta didik homogen yang termasuk perwakilan dari masing-masing kelompok yang heterogen. Peserta didik pada pembelajaran siklus I terlihat masih ragu karena belum pernah dilakukan selama ini. Peranan guru di sini sangat diharapkan untuk memberikan arahan peserta didik agar memahami konsep permaian TGT dengan baik. Hal ini bisa dilakukan guru dengan mendampingi peserta didik saat perrmainan turnamen.

Sebagaimana pendapat Slavin Slavin (2008:171) aktifitas TGT terdiri dari lima komponen salah satunya adalah fase III dan fase IV yaitu Games dengan struktur turnamen. Pada fase ini terdiri atas pertanyaan-pertanyaan yang dirancang untuk menguji pengetahuan yang didapat siswa dari penyajian kelas dan belajar kelompok. Kebanyakan game terdiri dari pertanyaanpertanyaan sederhana bernomor. Peserta didik memilih kartu bernomor dan mencoba menjawab pertanyaan yang sesuai dengan nomor itu. Peserta didik yang menjawab benar pertanyaan itu akan mendapatkan skor. Skor ini yang nantinya dikumpulkan untuk menentukan tim mana yang mendapat skor tertinggi dan akan diberi penghargaan sesuai pemenang dari game ini.

Berdasarkan pengamatan peneliti pada siklus I ini saat melakukan games turnamen peserta didik masih ragu, namun terlihat peserta didik merasa bahagia. Hal ini karena pada dasarnya peserta didik usia SD memang usia bermain, sebagai mana menurut BNSP (2009:7) bahwa salah satu karakteristik pembelajaran tematik adalah Menggunakan prinsip belajar sambil bermain dan menyenang-kan.

Kegiatan yang dilakukan oleh peserta didik selanjutnya adalah fase V (rekognisi), yaitu memberikan penghargaan kelompok terhadap hasil yang diperoleh berupa benda sesuai skor yang didapat, baik memperoleh skor super, sangat baik, baik maupun pavorit.

Fase kelima dari model pembelajaran kooperatif tipe TGT ini menurut Slavin (2008:171) adalah rekognisi tim, skor tim diperoleh dengan cara menjumlahkan skor anggota tim, kemudian dicari rata-ratanya. Berdasarkan skor rata-rata tim akan diperoleh gambaran perbedaan prestasinya. Dari skor rata-rata tim ini guru dapat memberikan penghargaan kepada setiap tim.

\section{Pembahasan Siklus II}

Pelaksanaan pembelajaran pada kegiatan inti difokuskan pelaksanaan fase-fase model kooperatif tipe TGTdari fase 1-5. Pada membentuk kelompok heterogen yang terdiri dari 4 orang. Kelompok yang dibentuk juga sama dengan kelompok pada siklus I dengan pertimbangan, bila ditukar kelompoknya akan memungkinkan peserta didik sulit untuk menyesuaikan diri dengan teman kelompok barunya.

Kelompok kerja peserta didik tersebut ditugaskan untuk berdiskusi tentang keadaan lingkungan sekolah dan rumah serta mencatat 
hasil diskusi dalam lembar kerja kelompok. Sebelum peserta didik diskusi kelompok, peserta didik diberikan arahan yang jelas tentang tugas yang akan dilakukannya.

Berdasarkan temuan penelitian, kegiatan diskusi kelompok yang dilakukan Peserta didik pada pembelajaran siklus II terlihat sudah menunjukkan kemampuan bekerja sama yang baik, peserta didik sudah terbiasa toleransi, terbiasa aktif dalam diskusi, mereka juga tidak malu-malu lagi untuk mempresentasikan hasil diskusinya, juga terbiasa berani mengungkapkan pendapat untuk memberikan tanggapan. Guru memberikan motivasi, baik secara verbal maupun non verbal.

Tanggapan yang disampaikan peserta didik tentang berhubungan dengan muatan pembelajaran pada siklus II, yaitu bahasa Indonesia, SBK, IPA, dan matematika. Pada kegiatan ini telah nampak bentuk kegiatan pembelajaran tematik, di mana pertukaran antara mata pelajaran yang satu dengan yang lainnya tidak terasa atau pembelajaran dilakukan tidak terpisah-pisah.

Kegiatan peserta didik selanjutnya adalah melakukan games turnamen dengan soal-soal yang sesuai tema pembelajaran siklus II yaitu lingkungan sekolah dan lingkungan rumah yang dikaitkan dengan kompetensi dasar muatan pembelajaran bahasa Indonesia, SBK, IPA, dan matematika. Berdasarkan pengamatan peneliti, kegiatan ini dilakukan peserta didik dengan kualifikasi baik. Hal ini dapat buktikan dengan peningkatan nilai proses dan hasil yang meningkat secara signifikan.

Selanjutnya setiap kelompok mendapatkan rekognisi tim sesuai predikat yang didapat, baik predikat super, sangat baik, baik maupun pavorit. Rekognisi berupa sertifikat dan juga hadiaah kue serta pujian dan motovasi dari guru.

\section{KESIMPULAN}

Terjadi

peningkatan proses pembelajaran tematik dengan menggunakan model kooperatif tipe $T G T$. Hal ini dapat dilihat permasalahan-permasalah yang terjadi di kelas III SD Negeri 18 Langgini Bangkinang dapat terselesaikan dengan baik. Proses pembelajaran tematik yang sudah berjalan efektif, guru tidak lagi mendominasi proses pembelajaran, peserta didik mulai aktif terlibat dalam proses pembelajaran, peserta didik sudah terbiasa bekerja kelompok dan dapat menghargai pendapat temannya.

\section{Implikasi}

Permasalah proses pembelajaran tematik di kelas III SD Negeri 18 Langgini Bangkinang Batusangkar yang belum efektif, dominasi guru dalam proses pembelajaran, peserta didik yang kurang terlibat dalam proses pembelajaran, peserta didik tidak terbiasa bekerja kelompok dan kurang menghargai pendapat temannya serta guru tidak pernah menerapkan model pembelajaran kooperatif. Dari permasalah diatas apabila dibiarkan dapat mengakibatkan permasalahpermasalah lain akan timbul. Peneliti berusaha memberi solusi dari permasalahan diatas dengan menerapkan model pembelajaran kooperatif tipe TGT. Berdasarkan hasil penelitan ternyata model pembelajaran kooperatif tipe TGTberhasil menyelesaikan permasalahan tersebut dengan baik.

Model pembelajaran kooperatif tipe $T G T$ sebagai solusi permasalah pembelajaran tematik kelas III SD Negeri 18 Langgini Bangkinang perlu ditindak lanjuti bagi kelas lain atau sekolah lain yang mempunyai permasalahan yang sama. Model pembelajaran tersebut perlu dilestarikan dengan cara melakukannya secara berulang-ulang sehingga menjadi budaya bagi guru dalam melaksanakan model pembelajaran. Hal ini karena model pembelajaran kooperatif tipe $T G T$ cocok diterapkan untuk peserta didik usia SD, karena model pembelajaran ini dilaksanakan melalui permaianan turnamen yang menyenangkan bagi peserta didik. Dengan pembelajaran yang dilakukan melalui aktifitas bermain sebagai salah satu ciri khas pembelajaran tematik menjadikan pembelajaran lebih bermakna. 
Tindak lanjut dari hasil penelitian ini adalah perlu diadakan pelatihan-pelatihan tentang model pembelajaran kooperatif tipe $T G T$. Sehingga model pembelajaran tersebut menjadi populer dikalangan guru. Dengan demikian proses pembelajaran tematik semakin meningkat.

\section{SARAN}

1. Disarankan guru menggunakan model pembelajaran kooperatif untuk menyelesaikan permasalahan pembelajaran tematik

2. Disarankan agar guru membiasakan peserta didik untuk bekerja kelompok

3. Disarankan guru mengikuti pelatihanpelatihan tentang model-model pembelajaran sehingga dalam melaksanakan proses pembelajaran lebih berkualitas.

\section{DAFTAR RUJUKAN}

Brandes and Ginnis.1990.A.Guide to Student Centred Learning.England: Basil Blackwell.

Cochran, Judith.1993.Everything You Need To Know To Be A successful Whole Lenguage teacher. Tennessee: Incentive Publications, Inc.

Collins and Dixon.1990.Integrated Learning.Bookshelf:Planet Curriculum Unit.

Daryanto dan Raharjo.2012. Model Pembelajaran Inovatif. Yogyakarta: Gava Media.

Desmita.2006. Psikologi

Perkembangan.Bandung:Remaja Rosda Karya.

Depdiknas . 2006. Kurikulum Tingkat

SatuanPendidikan. Jakarta: Badan

Standar Nasional Pendidikan.

Depdiknas.2009. Pembelajaran Tematik SD.

Jakarta: Badan Standar Nasional

Pendidikan.

Elida Prayitno.1992.Psikologi Perkembangan.

Jakarta: Depsikbud.
Farida Rahim, dkk. 2012. Bahan Ajar Bidang Studi untuk Guru Kelas Sekolah Dasar. Padang: UNP.

Hamalik Oemar.2012. kurikulum dan pembelajaran.Jakarta:Bumi aksara.

Kunandar.2010.Guru Profesional.Jakarta:PT Raja Grafindo Persada.

Permendiknas no 22 tahun 2006 tentang pendekatan pembelajaran kelas awal.

Robert E Slavin.2009.Teory, Research, and Practice. Boston Allyn and Bacon.

Rusman.2012.Model-Model pembelajaran.Jakarta: Raja Wali press.

Samatowa, Usman. 2011.Pembelajaran IPA di SD.Jakarta:Indeks

Sudjana, Nana,2009.Penilaian Hasil Proses Belajar Mengajar.Bandung:Remaja Rosda Karya.

Triyanto.2010.Mengembangkan Model Pembelajaran Tematik.Jakarta:Prestasi Pustaka Publisher.

Wahyudin.2008. Pembelajaran dan modelmodel pembelajaran.Jakarta: IPA Abong.

Wiriaatmadja, Rochiati. 2008. Metode Penelitian Tindakan Kelas. Bandung : Remaja Rosdakarya. 